\title{
RESEARCH
}

Open Access

\section{Organic mulching promotes soil organic carbon accumulation to deep soil layer in an urban plantation forest}

Xiaodan Sun 1,2,3, Gang Wang ${ }^{1,2}$, Qingxu Ma ${ }^{3}$, Jiahui Liao ${ }^{1,2}$, Dong Wang ${ }^{4}$, Qingwei Guan ${ }^{1,2^{*}}$ (D) and Davey L. Jones ${ }^{3,5}$

\begin{abstract}
Background: Soil organic carbon (SOC) is important for soil quality and fertility in forest ecosystems. Labile SOC fractions are sensitive to environmental changes, which reflect the impact of short-term internal and external management measures on the soil carbon pool. Organic mulching (OM) alters the soil environment and promotes plant growth. However, little is known about the responses of SOC fractions in rhizosphere or bulk soil to OM in urban forests and its correlation with carbon composition in plants.
\end{abstract}

Methods: A one-year field experiment with four treatments (OM at 0, 5, 10, and $20 \mathrm{~cm}$ thicknesses) was conducted in a 15-year-old Ligustrum lucidum plantation. Changes in the SOC fractions in the rhizosphere and bulk soil; the carbon content in the plant fine roots, leaves, and organic mulch; and several soil physicochemical properties were measured. The relationships between SOC fractions and the measured variables were analysed.

Results: The OM treatments had no significant effect on the SOC fractions, except for the dissolved organic carbon (DOC). OM promoted the movement of SOC to deeper soil because of the increased carbon content in fine roots of subsoil. There were significant correlations between DOC and microbial biomass carbon and SOC and easily oxidised organic carbon. The OM had a greater effect on organic carbon fractions in the bulk soil than in the rhizosphere. The thinnest $(5 \mathrm{~cm})$ mulching layers showed the most rapid carbon decomposition over time. The time after OM had the greatest effect on the SOC fractions, followed by soil layer.

Conclusions: The frequent addition of small amounts of organic mulch increased SOC accumulation in the present study. OM is a potential management model to enhance soil organic matter storage for maintaining urban forest productivity.

Keywords: Soil organic carbon, Labile organic carbon fractions, Rhizosphere, Urban plantation forest, Organic mulching

\footnotetext{
*Correspondence: guanjapan999@163.com

${ }^{1}$ College of Biology and Environment, Nanjing Forestry University, Nanjing

210037, China

${ }^{2}$ Co-Innovation Center of Sustainable Forestry in Southern China, Nanjing

210037, China

Full list of author information is available at the end of the article
}

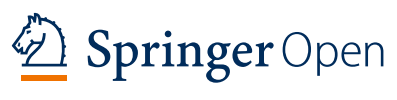

(c) The Author(s). 2021 Open Access This article is licensed under a Creative Commons Attribution 4.0 International License, which permits use, sharing, adaptation, distribution and reproduction in any medium or format, as long as you give appropriate credit to the original author(s) and the source, provide a link to the Creative Commons licence, and indicate if changes were made. The images or other third party material in this article are included in the article's Creative Commons licence, unless indicated otherwise in a credit line to the material. If material is not included in the article's Creative Commons licence and your intended use is not permitted by statutory regulation or exceeds the permitted use, you will need to obtain permission directly from the copyright holder. To view a copy of this licence, visit http://creativecommons.org/licenses/by/4.0/. 


\section{Background}

Forest soil organic carbon (SOC) accounts for about $70 \%$ of global SOC, which is an important part of the global terrestrial ecosystem and is vital for soil quality and fertility (Jandl et al. 2007; Shen et al. 2018). Labile SOC fractions, such as dissolved organic carbon (DOC), easily-oxidised organic carbon (EOC), and microbial biomass carbon $(\mathrm{MBC})$, account for approximately $10 \%$ of total organic carbon (Sainepo et al. 2018) and have emerged as standardised indicators because of their potential to detect early SOC trends over time (Ramírez et al. 2020). They are the most active fractions of SOC; they have rapid turnover rates (Chen et al. 2019), are more responsive to changes in forest management strategies, and have helped explain the mechanism of SOC retention (Chen et al. 2019). Labile SOC fractions also participate in many ecological processes and play an important role in soil nutrient availability and soil quality improvement (García-Díaz et al. 2018).

Plantations in China account for approximately onethird of the world's planted forest area and the total area of plantations in China is 79.54 million ha (State Forestry Administration of China 2014). Recent studies have shown that management practices, such as fertilisation and under-forest litter removal, significantly reduce SOC stocks, owing to the increased decomposition of soil organic matter and decreased carbon input to soil, and increase soil respiration (Li et al. 2013; Vogel et al. 2015), with subsequent negative impacts on carbon sequestration in forest soils. Therefore, the consequences for soil carbon should be considered before land management policies are put forth. Organic mulching (OM) is one measure that can effectively change the soil environment and provide available nutrients for plants ( $\mathrm{Li}$ et al. 2013; Vogel et al. 2015). The application of organic mulch changes the nutrient cycle and energy flow between the soil and plants and alters SOC dynamics. $\mathrm{OM}$ improves soil properties by adding carbon and nutrient sources through the decomposition of organic matter; thus, OM directly increases SOC. Furthermore, more SOC is transported to soil through the roots when plants absorb more nutrients from organic mulch (Sasse et al. 2018; Wang et al. 2018). Organic mulching also accelerates soil respiration and $\mathrm{CO}_{2}$ emissions, making it uncertain whether its use would promote SOC pool storage or loss (Lenka and Lal 2013) because labile SOC fractions are reset in the short term (Kuzyakov 2010). More recent research has suggested that soil carbon varies over time with the decomposition of organic matter and, especially for the rhizosphere, the priming effect may be long-lasting after litter addition (Chen and Chen 2018). The effects of OM on SOC fractions are controversial (Li et al. 2010; Wang et al. 2018) and its mechanism of action has not been clarified. Furthermore, the effect of OM may vary between ecosystems, but most studies have focused on agriculture, with few investigating forest ecosystems.

Labile SOC fractions have distinct seasonal dynamics and soil microbial carbon is likely driven by climate (precipitation and temperature) and soil physicochemical properties rather than by nutrient addition (Shao et al. 2015; Jing et al. 2020). Therefore, time (i.e., season) may be a critical factor that impacts SOC fractions and should be considered in studies. Soil depth is another important factor that may significantly affect SOC fractions. The topsoil is more directly and strongly affected by external interferences, such as fertilisation than the subsoil, but the stability of the subsoil is also controlled by fresh organic matter (Shao et al. 2015; Jing et al. 2020). Added nutrients increase the growth of trees, which promotes root turnover and horizontal or vertical growth. Roots are an important source of SOC (Wang et al. 2019a), and changes in carbon composition of the roots after OM will affect the soil carbon fractions. The uncertainty of the direction of plant root growth may lead to a variety of organic carbon fractions in different soil layers after OM (Fontaine et al. 2007). Therefore, the response of soil carbon fractions at different depths to land management is controversial (Hicks Pries et al. 2018; Borchard et al. 2019). Some studies have shown that SOC and its active fractions decrease with increasing soil depth in all OM applications (Gu et al. 2016), whereas a 12-year field experiment showed that the effects of mulching treatments on different labile SOC fractions at different soil layers are distinct (Zhou et al. 2019).

The rhizosphere is a special ecological interface that connects root systems and soil and is strongly influenced by the plant root system and microbial activity (Kuzyakov and Xu 2013; York et al. 2016). Nutrient cycling and energy conversion are more rapid in the rhizosphere than in bulk soil (Cheng et al. 2014). The physical, chemical, and biological properties of the rhizosphere and bulk soil differ after nutrient addition (Phillips and Fahey 2007). As an important site for plant-soilmicroorganism interactions, the combination of the rhizosphere and the bulk soil environments may provide an important window in understanding the mechanism of soil-plant interactions. Accordingly, we tested changes in the SOC fractions in the rhizosphere and bulk soil after four OM treatments over a period of 1 year. We measured the carbon content in the plant fine roots, leaves, and organic mulch, as well as several soil physicochemical properties, to analyse the relationships between SOC fractions and the measured variables. We hypothesised that: (1) OM would significantly affect SOC fractions and that DOC would be the most variable carbon fraction; and (2) with the decomposition of the organic 
mulch, the carbon input through the production and turnover of fine roots should increase because of improvements in the soil properties and plant growth, which will then increase rhizosphere deposition and promote SOC storage.

\section{Materials and methods}

\section{Study area and experimental design}

The study was conducted in the forest in Xiaolingwei, Xuanwu District, Nanjing City, China $\left(32^{\circ} 02^{\prime} 37^{\prime \prime}-\right.$ $32^{\circ} 02^{\prime} 39^{\prime \prime} \mathrm{N}, 118^{\circ} 49^{\prime} 41^{\prime \prime}-118^{\circ} 49^{\prime} 43^{\prime \prime}$ E, $37 \mathrm{~m}$ altitude, flat terrain). The experimental plot has a northern subtropical monsoon climate, an annual precipitation of $1000-1050 \mathrm{~mm}$, an annual average temperature of $15.4^{\circ} \mathrm{C}$, and 2213 annual sunshine hours on average. According to the historical records of Zhongshan Cemetery in Nanjing, buildings were originally present in the area but later demolished, and the region is currently covered with $50-60 \mathrm{~cm}$ thick layer of soil (mainly allochthonous) and planted trees. We chose 15-year-old pure Ligustrum lucidum W.T.Aiton (Broad-leaf privet; family, Oleaceae) forest, the most common evergreen plantation type in southern China, with tree spacings of more than $2 \mathrm{~m}$ and canopy densities of approximately 0.85 for this study. The average tree height was $7.5 \mathrm{~m}$, and the average diameter at breast height was $10.9 \mathrm{~cm}$. Soil physical and chemical properties are shown in Table 1.

Four adjacent trees were randomly selected as one experimental plot, and a total of 32 experimental plots were established. The area of each plot was approximately $16 \mathrm{~m}^{2}$ and these plots were concentrated and uniformly distributed in the experimental area. Individual trees were randomly allocated to one of four treatments, namely mulch placed around the tree on the soil surface to a depth of either $0,5,10$, or $20 \mathrm{~cm}$ (i.e., 0,35 , 70 , and $140 \mathrm{~kg}$ of mulch/tree, respectively; codes OM0, OM5, OM10, and OM20) in each plot. The mulch extended $80 \mathrm{~cm}$ away from the trunk allowing a $>0.5-\mathrm{m}$ buffer between the trees. The treatments were completed by the end of November 2017. The organic mulch consisted of composted municipal green waste derived from urban gardens and was produced by Shanghai Moqi Garden Co., Ltd. (Shanghai, China). The basic physical and chemical properties of the mulch are shown in Table 2.

\section{Sample collection}

Samples were taken after 6, 9, and 12 months of OM (i.e., May, August, and November 2018, respectively), and five experimental plots (i.e., $n=5$ per treatment) were randomly selected for each treatment at each monitoring point. Each experimental plot was used only once in the entire experiment. Soil profiles were dug $50 \mathrm{~cm}$ away from the main trunk of the plant, and each profile was divided into two layers $(0-20$ and $20-40 \mathrm{~cm}$ below the mulch layer). Soil blocks of $20 \mathrm{~cm} \times 20 \mathrm{~cm} \times 20 \mathrm{~cm}$ were dug from each layer, and the "rhizosphere" soil was collected by gently shaking off soil adhering to the roots. The remaining soil was bulk soil. The fine roots $(<2$ $\mathrm{mm}$ in diameter) in each plot, leaves on the sampled tree, and organic mulch of each treatment were collected. Soil samples were taken using cylindrical steel cores $\left(100 \mathrm{~cm}^{3}\right)$ for the determination of bulk density (BD) in each soil profile, and the soil and plant samples were placed in self-sealing bags and immediately transported to the laboratory for testing. Soil temperature of different soil layers was recorded in situ using Thermochron temperature loggers (DS1923Hygrochron; OnSolution Pty Ltd., Baulkham Hills, NSW, Australia).

\section{Measurement methods}

The soil $\mathrm{pH}$ was determined using a glass electrode $\mathrm{pH}$ meter (PHS-3C; Leici Inc., Shanghai, China) with a soil: water ratio of 1:2.5. After air-drying, the soil samples were sifted through $0.149-\mathrm{mm}$ meshes and SOC and total nitrogen were determined using an elemental analyser (Elemental Vario EL; Elementar, Langenselbold, Germany). The DOC was determined using an organic carbon analyser (TOC-VCPH + TNM-1; Shimazu Inc., Kyoto, Japan) (Jones and Willett 2006). Easily-oxidised organic carbon was determined using the $\mathrm{KMnO}_{4}$ oxidation method (Blair et al. 1995). The MBC $(\mathrm{Kc}=0.45)$ and microbial biomass nitrogen $(\mathrm{Kc}=0.54)$ were determined using the chloroform fumigation- $\mathrm{K}_{2} \mathrm{SO}_{4}$ extraction method and values were obtained using the organic carbon analyser (Brookes et al. 1985; Wu et al. 1990). Ammonium and nitrate were determined using a continuous flow analyser (San++; Skalar, Breda, Netherlands). Soil organic matter was determined after digestion by the $\mathrm{K}_{2} \mathrm{Cr}_{2} \mathrm{O}_{7}$ titration method. Total phosphorus and available phosphorus were determined by molybdenum blue colourimetry. Total potassium was

Table 1 Physicochemical properties of the soil used in the study

\begin{tabular}{|c|c|c|c|c|c|c|c|c|c|}
\hline $\begin{array}{l}\text { Soil } \\
\text { layer (cm) }\end{array}$ & $\mathrm{pH}$ & $\begin{array}{l}\text { Total } \\
\text { carbon } \\
\left(\mathbf{g} \cdot \mathrm{kg}^{-1}\right)\end{array}$ & $\begin{array}{l}\text { Total } \\
\text { nitrogen } \\
\left(\mathbf{g} \cdot \mathrm{kg}^{-1}\right)\end{array}$ & $\begin{array}{l}\text { Total } \\
\text { phosphorus } \\
\left(\mathbf{g} \cdot \mathrm{kg}^{-1}\right)\end{array}$ & 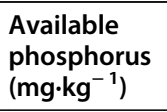 & $\begin{array}{l}\text { Total } \\
\text { potassium } \\
\left(\mathbf{g} \cdot \mathrm{kg}^{-1}\right)\end{array}$ & $\begin{array}{l}\text { Available } \\
\text { potassium } \\
\left(\mathbf{g} \cdot \mathrm{kg}^{-1}\right)\end{array}$ & $\begin{array}{l}\mathrm{NO}_{3}^{-}-\mathrm{N} \\
\left(\mathrm{mg} \cdot \mathrm{kg}^{-1}\right)\end{array}$ & $\begin{array}{l}\mathrm{NH}_{4}{ }^{+}-\mathrm{N} \\
\left(\mathrm{mg} \cdot \mathrm{kg}^{-1}\right)\end{array}$ \\
\hline $0-20$ & 7.29 & 13.12 & 1.58 & 0.40 & 29.02 & 1.08 & 0.14 & 1.71 & 2.50 \\
\hline $20-40$ & 7.31 & 11.20 & 1.42 & 0.32 & 23.12 & 0.95 & 0.13 & 1.69 & 1.43 \\
\hline
\end{tabular}


Table 2 Physicochemical properties of the organic mulch used in the study

\begin{tabular}{cccccccccc}
\hline $\mathbf{p H}$ & $\begin{array}{l}\text { Dry density } \\
\left(\mathbf{M g} \cdot \mathbf{m}^{-3}\right)\end{array}$ & $\begin{array}{l}\text { Wet density } \\
\left(\mathbf{M g} \cdot \mathbf{m}^{-3}\right)\end{array}$ & $\begin{array}{l}\text { Electrical } \\
\text { conductivity } \\
\left(\mathbf{m S} \cdot \mathbf{c m}^{-\mathbf{1}}\right)\end{array}$ & $\begin{array}{l}\text { Porosity } \\
\left(\mathbf{m}^{3} \cdot \mathbf{m}^{-3}\right)\end{array}$ & $\begin{array}{l}\text { Organic } \\
\text { matter } \\
\left(\mathbf{g} \cdot \mathbf{k g}^{-1}\right)\end{array}$ & $\begin{array}{l}\text { Total } \\
\text { carbon } \\
\left(\mathbf{g} \cdot \mathbf{k g}^{-1}\right)\end{array}$ & $\begin{array}{l}\text { Total } \\
\text { nitrogen } \\
\left(\mathbf{g} \cdot \mathbf{k g}^{-1}\right)\end{array}$ & $\begin{array}{l}\text { Total } \\
\mathbf{p h o s p h o r u s} \\
\left(\mathbf{g} \cdot \mathbf{k g}^{-1}\right)\end{array}$ \\
\hline 6.40 & 0.14 & 0.79 & 1.35 & 317.80 & 902.00 & 598.50 & 23.80 & $\begin{array}{l}\text { Total } \\
\text { potassium } \\
\left(\mathbf{g} \cdot \mathbf{k g}^{-1}\right)\end{array}$ \\
\hline
\end{tabular}

determined by inductively coupled plasma-atomic emission spectroscopy (ICP-AES) (ICAP6300; Thermo Fisher Scientific, Waltham, MA, USA) after wet digestion with $\mathrm{HClO}_{4}$-HF. Available potassium was extracted with 1 $\mathrm{mol} \cdot \mathrm{L}^{-1} \mathrm{CH}_{3} \mathrm{COONH}_{4}(\mathrm{pH}=7.0)$ solution and measured by ICP-AES after filtering. The collected fine roots and leaves were washed and dried to a constant mass in an oven at $65^{\circ} \mathrm{C}$. Organic mulch samples were air-dried and then ground and sifted through $0.149-\mathrm{mm}$ meshes. The $\mathrm{C}$ content of these samples was determined using an elemental analyser. The moisture content was determined by oven-drying the samples at $105^{\circ} \mathrm{C}$.

\section{Data analysis}

All statistical analyses were conducted using R Studio Version 1.1.463 (R Studio, Inc., Boston, MA, USA) (R Development Core Team 2018). To evaluate differences in SOC fractions among treatments and soil layers, as well as their interactions, linear mixed-effects models were calculated using the R package "Ime4" (Bates et al. 2015). Treatment (four levels), soil layer (two levels), time after OM (season, three levels), and their interactions (three-way) were treated as fixed factors and the sampling plots were treated as random factors. Because the interaction of these three factors has no significant effect on SOC fractions, a comparison of SOC fractions between the rhizosphere and bulk soil was carried out using the Tukey pairwise comparison test. The figures and the redundancy analysis were created using the "ggplot2" and "vegan" (Oksanen et al. 2019) software packages in $R$, respectively. Statistical significance was determined at $P<0.05$.

\section{Results}

Effects of OM on SOC fractions in the rhizosphere and bulk soil

Time was the main factor affecting the SOC fractions (expect for EOC in the bulk soil), followed by soil layer, whereas treatments had no significant effect on the labile SOC fractions, with the exception of DOC (Table 3). The interactions among time after OM, soil layer, and treatments had no significant impact on any of the labile SOC fractions. The SOC and EOC after the different treatments were lower compared with those in $\mathrm{OM} 0$ at the beginning of $\mathrm{OM}$, and subsequently increased (12 months after OM), except for those in the bulk soil. The $\mathrm{SOC}$ fractions showed a different trend for seasonal variations, but for the same fraction in the topsoil $(0-20 \mathrm{~cm})$ and subsoil $(20-40 \mathrm{~cm})$, as well as that in rhizosphere and bulk soil, they had the same trend of change (Fig. 1). The DOC and MBC decreased gradually over time, whereas SOC initially decreased before increasing, with EOC showing no obvious change. The DOC and MBC decreased in the topsoil after 6 months of $\mathrm{OM}$ in the bulk soil, and then subsequently increased (compared with those in OM0). The DOC in the topsoil rhizosphere decreased again in the non-growing season.

\section{Changes in carbon content in plants and organic mulch}

The carbon content in the fine roots was the highest in the non-growing season (12 months after OM; Fig. 2). After OM, the carbon content in the fine roots initially decreased in the topsoil and then increased, whereas it initially increased and then decreased in the subsoil. The carbon content in the organic mulch gradually decreased

Table 3 Analysis of the variance of the effects of different treatments, soil layers, and time after organic mulching on soil organic carbon fractions in the rhizosphere and bulk soil

\begin{tabular}{|c|c|c|c|c|c|c|c|c|c|}
\hline & \multirow[t]{2}{*}{$d f$} & \multicolumn{2}{|c|}{ Soil organic carbon } & \multicolumn{2}{|c|}{$\begin{array}{l}\text { Dissolved } \\
\text { organic carbon }\end{array}$} & \multicolumn{2}{|c|}{$\begin{array}{l}\text { Easily-oxidised } \\
\text { organic carbon }\end{array}$} & \multicolumn{2}{|c|}{$\begin{array}{l}\text { Microbial } \\
\text { biomass carbon }\end{array}$} \\
\hline & & Bulk Soil & Rhizosphere & Bulk Soil & $\overline{\text { Rhizosphere }}$ & Bulk Soil & Rhizosphere & Bulk Soil & Rhizosphere \\
\hline Time & 2 & $9.73 * * *$ & $10.69 * * *$ & $114.48^{* * *}$ & $82.63^{* * *}$ & $7.28^{* *}$ & 1.41 & $96.71 * * *$ & $136.83^{* * *}$ \\
\hline Soil layer & 1 & $10.40^{* *}$ & $4.49 *$ & $25.49 * * *$ & $13.59^{* * *}$ & $83.73 * * *$ & $74.29^{* * *}$ & $29.61^{* * *}$ & $17.31^{* * *}$ \\
\hline Treatment & 3 & 0.48 & 0.15 & $5.06^{* *}$ & $4.12^{*}$ & 1.27 & 0.83 & 0.30 & 0.37 \\
\hline Time $\times$ Soil layer & 2 & $5.99^{* *}$ & 3.01 & 0.55 & 0.09 & 0.75 & 1.65 & 0.04 & 2.67 \\
\hline Time $\times$ Treatment & 6 & 1.02 & 0.86 & 0.92 & 2.11 & $2.94^{*}$ & 1.74 & 0.17 & 0.29 \\
\hline Soil layer $\times$ Treatment & 3 & 0.97 & 0.62 & 1.78 & 0.87 & $3.62^{*}$ & 0.20 & 2.22 & 1.18 \\
\hline Time $\times$ Soil layer $\times$ Treatment & 6 & 1.08 & 0.44 & 0.98 & 0.89 & 0.73 & 0.60 & 1.36 & 0.66 \\
\hline
\end{tabular}

Note: ${ }^{*} P<0.05 ; * P<0.01 ; * * P<0.001$ 


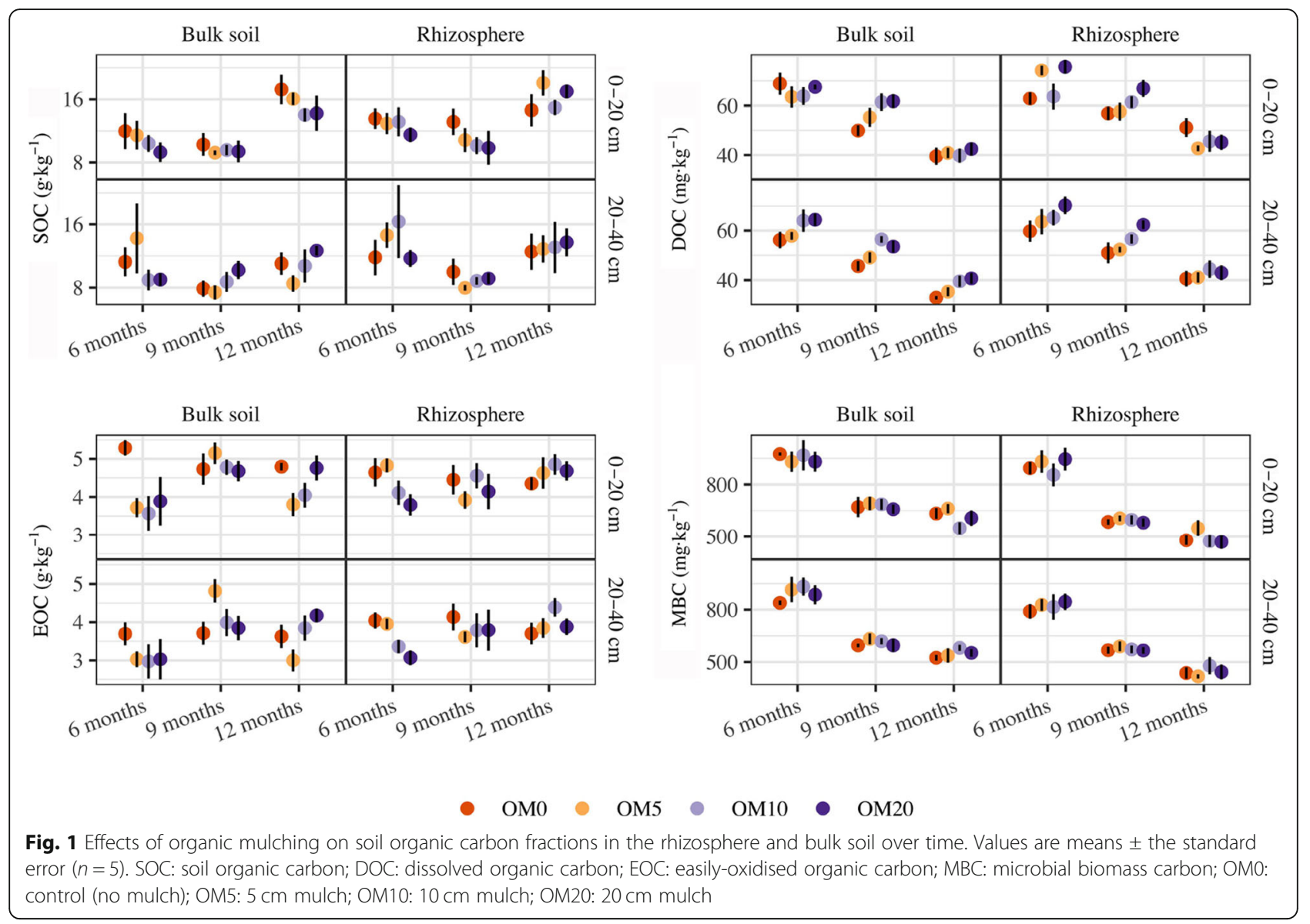

over time, but there were no significant differences in carbon content at the same sampling among the different treatments. After OM, the carbon content in the leaves initially increased and then decreased compared with OM0, and as the amount of mulch increased, the differences between the treatments and OMO gradually decreased.

\section{Association between labile SOC fractions and the physicochemical properties of soil and carbon content in plants}

The SOC fractions in the rhizosphere were correlated with those in the bulk soil (Fig. 3; Table S1). There was a significant correlation between $\mathrm{DOC}$ and $\mathrm{MBC}$ and between SOC and EOC. The SOC fractions in the rhizosphere and bulk soil were significantly correlated with most of the soil physicochemical properties (Fig. 3; Table S2). There was a significant positive correlation between $\mathrm{SOC}$ and the $\mathrm{C} / \mathrm{N}$ ratio. The $\mathrm{DOC}$ was mainly related to water content, followed by ammonium and nitrate. The $\mathrm{MBC}$ was mostly related to water content followed by ammonium. Temperature and BD were also important factors associated with SOC and DOC. The carbon content in the fine roots was negatively correlated with that in the organic mulch and was strongly correlated with other carbon fractions except with EOC in the rhizosphere and SOC. With the exception of EOC, the carbon content in the leaves was related to the other carbon fractions.

\section{Discussion}

Response of SOC fractions to OM

With the exception of DOC, OM had no significant effect on SOC fractions (Table 3), which indicates that the labile SOC fractions are stable for a short time (within half a year) after OM. This result agrees with other studies, which demonstrated that straw mulch has no obvious effect on the labile SOC fractions over different periods of time and that the SOC content does not change with management practice over the short term because of a high background carbon concentration and spatial variability (Gu et al. 2016; Zhang et al. 2018). However, other studies have shown that both labile SOC fractions and carbon pool activity increase significantly after straw return under an annual wheat/maize rotation system (Dong et al. 2018; Li et al. 2019). The continuous application of straw mulch over time can increase soil carbon sequestration by increasing stable carbon fractions 

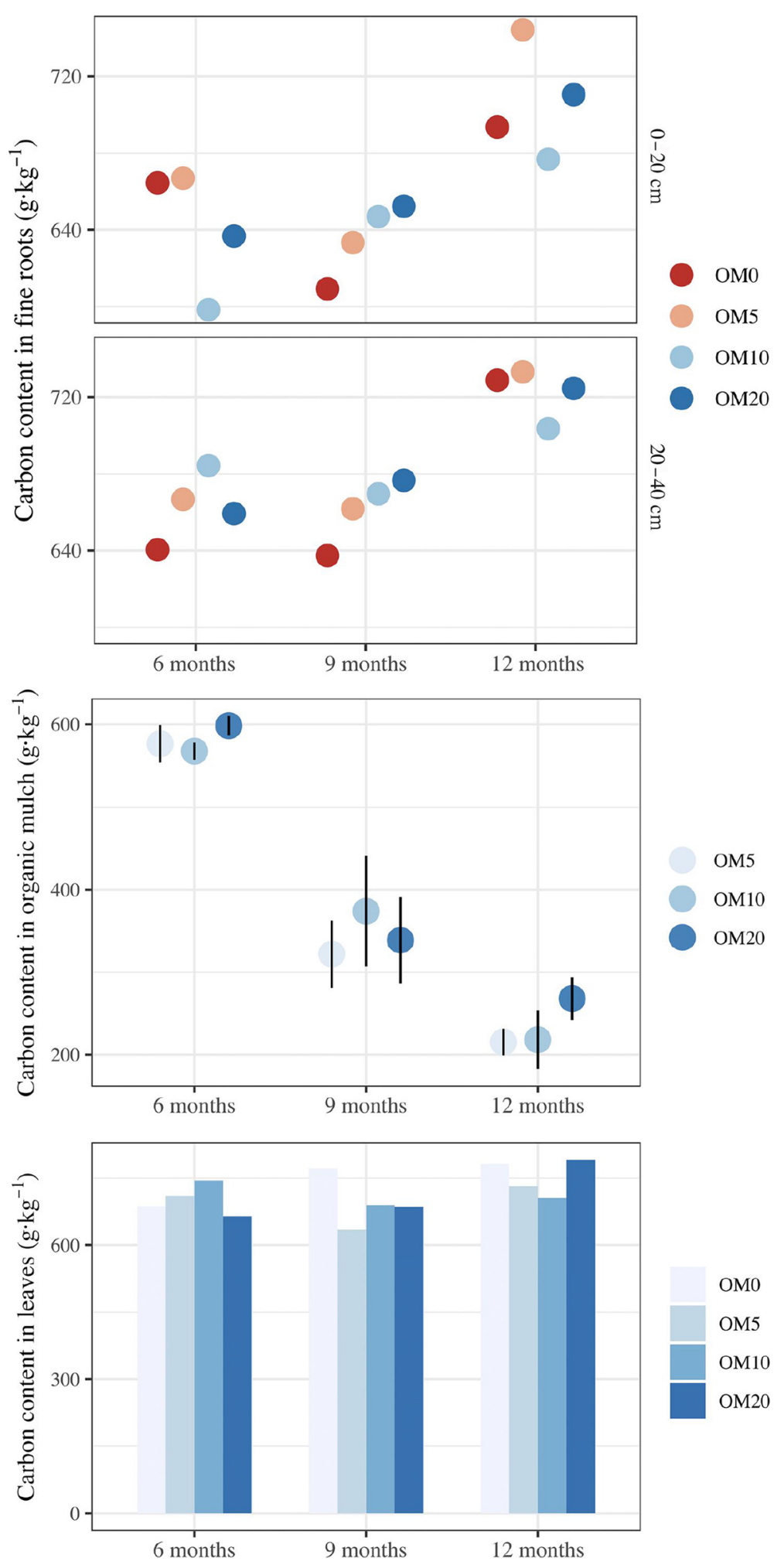

Fig. 2 Carbon content in fine roots, leaves, and organic mulch over time after organic mulching ( $X$ axis). OM0: control (no mulch); OM5: $5 \mathrm{~cm}$ mulch; OM10: $10 \mathrm{~cm}$ mulch; OM20: $20 \mathrm{~cm}$ mulch 


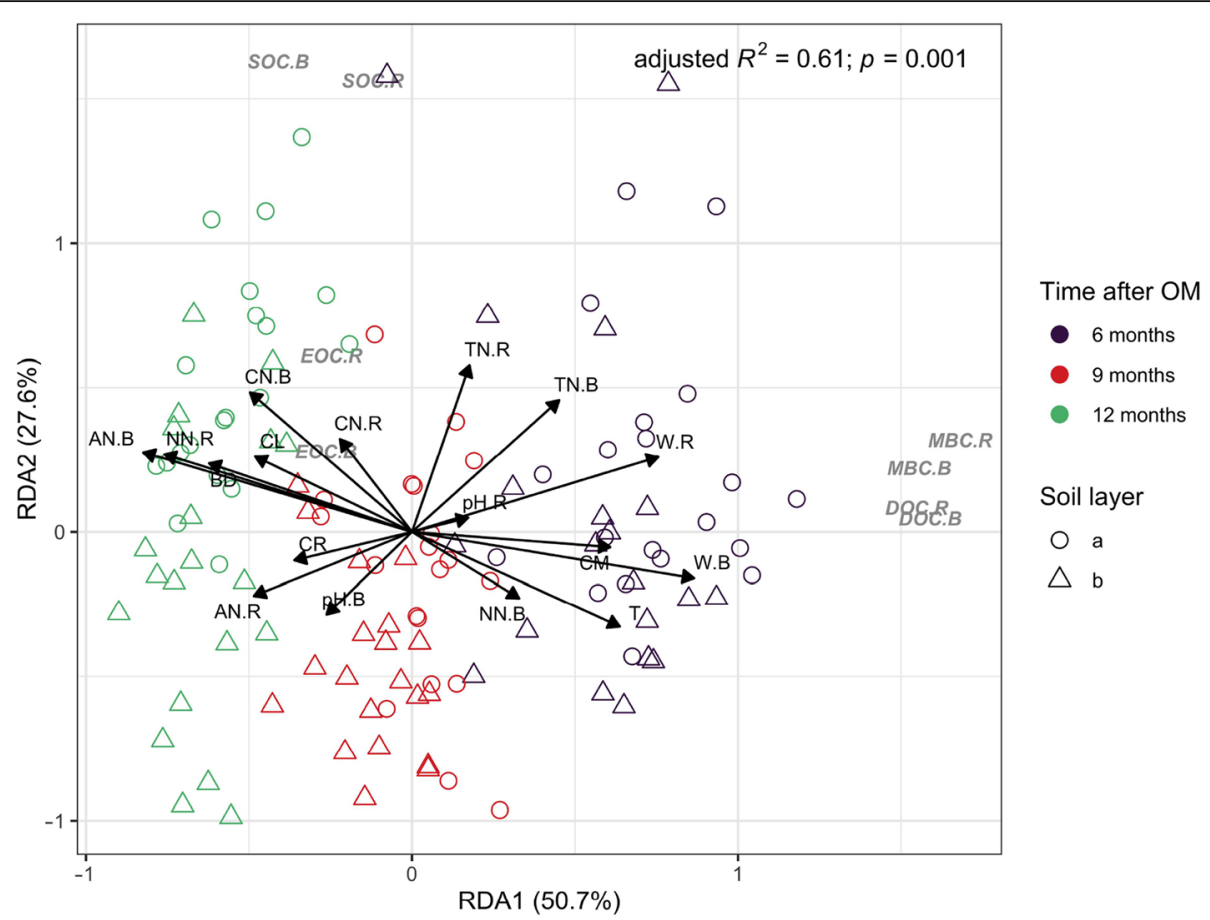

Fig. 3 Redundancy analysis ordination plot of soil organic carbon fractions constrained by environmental variables that significantly explain variation. SOC: soil organic carbon; DOC: dissolved organic carbon; EOC: easily-oxidised organic carbon; MBC: microbial biomass carbon; BD: bulk density; $\mathrm{T}$ : temperature; $\mathrm{W}$ : water content; $\mathrm{TN}$ : total nitrogen; $\mathrm{AN}$ : ammonium; NN: nitrate; $\mathrm{CR}$ : carbon content in fine roots; $C \mathrm{~L}$ : carbon content in leaves; CM: carbon content in organic mulch. ".B" means "in bulk soil" and ".R" means "in rhizosphere"

and simultaneously decreasing labile fractions (Wang et al. 2018). The reasons for the differences in these results may be related to the organic matter property, soil property, sampling time, or other factors. In our study, SOC initially decreased in the topsoil, whereas OM increased the SOC in the subsoil, especially OM5, with lower amounts of mulch that are easily decomposed in the soil. We ascribe this to the following factors:

1) Organic mulching improves the soil water content in the growing season, which promotes the leaching of soil nutrients into the deeper soil layer and the movement of organic carbon from the topsoil to the subsoil. In parallel, a large number of organic acids are produced during the decomposition of organic mulch (Haynes and Mokolobate 2001), which intensifies the leaching of carbon components into the native soil. In addition, the increased temperature after organic mulching decreased forest topsoil SOC content (Sun et al. 2019).

2) Fine roots play an important role in forming SOC (Sokol et al. 2019) and the main source of SOC is usually through rhizosphere deposition (Chen and Chen 2018). In our study, OM promoted carbon accumulation in the fine roots of the deeper soil in the growing season and the carbon content in the fine roots showed the same trend as the SOC, especially in the rhizosphere (Fig. 2). Organic carbon transported downward through the roots increases when plants absorb more nutrients from the organic mulch (Sasse et al. 2018; Wang et al. 2019b). This could be because fine roots are more sensitive to nutrients in the subsoil than those in the topsoil (Björk et al. 2007; Wang et al. 2019b). The changes in carbon content in the fine roots are consistent with those observed for SOC in the soil, which provides important evidence for a decrease in SOC in the topsoil after OM.

3) After OM, the input of organic matter stimulates the decomposition of the original stable soil carbon in the topsoil (Björk et al. 2007; Wang et al. 2019b). Environmental changes could also destroy the balance between previous carbon inputs and outputs by accelerating the decomposition of unstable and semi-stable organic carbon (Wang et al. 2012). The carbon-nitrogen ratio ( $\mathrm{C} / \mathrm{N}$ ratio) in the bulk soil decreased initially (Fig. S1), implying that the input of organic matter promotes the utilisation of a large number of carbon sources; thus, available carbon, such as DOC and MBC (Fig. 1). Furthermore, OM increases soil porosity by decreasing $\mathrm{BD}$, which may promote soil respiration and $\mathrm{CO}_{2}$ emission, resulting in carbon loss in the topsoil at this stage at levels that 
exceed the stable carbon derived from the addition of organic matter.

4) In our study, SOC was mainly correlated with the $\mathrm{C} / \mathrm{N}$ ratio (Fig. 3; Table $\mathrm{S} 2$ ). The $\mathrm{C} / \mathrm{N}$ ratio in the original soil was low (Table 1); the input of a new source with high $\mathrm{C} / \mathrm{N}$ ratio (Table 2) promoted more active carbon fractions because the labile SOC fractions/SOC (i.e., DOC/EOC, EOC/SOC, and $\mathrm{MBC} / \mathrm{EOC}$ ) ratio increased after OM (Fig. S1). An important mediator of the belowground responses of trees to elevated $\mathrm{CO}_{2}$ is nitrogen availability and low nitrogen supply will increase the carbon allocation of plants to roots (Phillips et al. 2011). Thus, the stimulation has a greater impact on the upper layer and the stable organic carbon in the subsoil increases more.

5) During the sampling process, we found more earthworms in the soil with treatments than OM0, which stimulates vertical bioturbation and transport of carbon to the subsoil (Birkhofer et al. 2008). This could explain why SOC decreased in the topsoil.

The decrease in labile SOC fractions in the subsoil at the beginning of the growing season is also related to nutrient leaching and water drainage into the deeper soil. From the later growing season, the carbon content in the fine roots increased in the topsoil compared with that in OM0 (Fig. 2), which indicates that OM accelerates carbon accumulation in the fine roots by promoting plant growth.

The DOC and MBC showed the same trend in their changes (Fig. 1), and their strong positive correlation (Table S1) might be mainly because they were both significantly affected by water content, ammonium, and nitrate (Fig. 3; Table S2). Organic mulching is conducive to water conservation. Additionally, the addition of organic matter directly adds DOC and the decomposition of organic matter stimulates microorganisms to produce more $\mathrm{MBC}$ and available nitrogen (ammonium and nitrate) in the soil (Li et al. 2016; Dong et al. 2018). Among the labile SOC fractions, OM only had a significant effect on DOC (Table 3), indicating that this fraction is more sensitive than the others to OM. On the one hand, OM improves soil physical properties (Pramanik et al. 2015; Nawaz et al. 2017), which provides a relatively favourable environment for DOC owing to its correlation with these physical soil traits (Fig. 3; Table S2). On the other hand, the DOC is derived principally from biotic degradation processes, in which soil microorganisms are the main players, and from root exudates (Balland-Bolou-Bi et al. 2019). OM provides additional organic matter that can decompose and leach into the soil, promoting plant growth that, in turn, produces more root exudates and rhizodeposition and stimulates microbial activity (which also explains the significant correlation between DOC and $\mathrm{MBC}$ ). The increased carbon from plants (especially from the roots) after OM enhanced the DOC because carbon content in mulch, fine roots, and leaves was significantly correlated with DOC (Fig. 3; Table S2). Some researchers have found that MBC is the most sensitive indicator of SOC changes following treatment with straw mulch (Balland-Bolou-Bi et al. 2019). The microbial biomass changes rapidly with changes in the external environment over a short period of time (Sinsabaugh et al. 2015). As we only took samples at a limited number of time points, this could be a limitation in this study.

Change in SOC fractions in the rhizosphere and bulk soil Our results suggest that there was a greater variation in the bulk soil than in the rhizosphere after OM. A large number of studies have shown that the rhizosphere is more sensitive to external disturbance than the bulk soil (Phillips and Fahey 2007; De Feudis et al. 2017). However, in our experiment, the nutrients in the soil continuously decreased in the process of transfer to the plants after OM, which caused the environmental change from soil to the rhizosphere to gradually weaken. To a certain extent, this process weakened the OM stimulation on the rhizosphere; thus, OM has a different intensity of action on the rhizosphere and bulk soil depending on the nutrient gradients (Kuzyakov and Razavi 2019). Our results also showed that only time had a significant effect on the rhizosphere effects of EOC and MBC (Table S3). The rhizosphere environment can be stable over the short term, but our sampling times $(6,9$ and 12 months after $\mathrm{OM}$ ) were much longer or missed the peak time of the priming effect (Kuzyakov et al. 2000). Furthermore, the soil at our experimental site was transported from elsewhere. During the sampling process, the plant roots were shallowly distributed, there was a less extensive root system in the subsoil, and the interaction between the rhizosphere soil and the plant roots was weak, all of which may have led to a weak rhizosphere effect on carbon fractions.

\section{Effect of time and soil layer on SOC fractions}

The time after OM (i.e., season) had the greatest impact on the SOC fractions, followed by soil layer in our study (Table 3). Different sampling times resulted in variability in several environmental factors (e.g., water and temperature), which are important indicators that affect the soil carbon pool (Kawahigashi et al. 2003; Xue et al. 2018). Therefore, the response of the SOC fractions to soil management varies with time (Kawahigashi et al. 2003; Xue et al. 2018). For instance, seasonal variations in climate, site conditions, and soil physicochemical properties affect changes in the soil DOC content (Kawahigashi et al. 2003). The different distribution of 
root exudates and soil microorganisms in the different soil layers leads to a variety of different soil profile environments (Angst et al. 2018), which may cause significant differences in the SOC fractions at different depths. Soil nutrients decrease with increases in soil depth (Angst et al. 2018) and the SOC fractions were closely related to soil nutrients in this study (Fig. 3; Table 3). Furthermore, the upper soil is more directly affected by the addition of organic mulch and the available nutrients in the topsoil are higher than those in the subsoil. The increasing carbon content in the fine roots in the subsoil (Fig. 2) contributes to the SOC fractions in the subsoil. Of these factors, the one that plays a dominant role may determine the content of the SOC fractions in different soil layers. Accordingly, both time and soil layers are essential factors that affect SOC fractions, which should be accounted for in $\mathrm{OM}$ and other land management research.

\section{Changing processes of soil carbon fractions in soil and plants after OM}

We suggest that the addition of organic mulch initially improved the water content and soil porosity (BD decreased), causing the downward movement of soil carbon fractions and the downward growth of fine roots at the beginning of the growing season ( 6 months after $\mathrm{OM})$. This, in turn, promoted SOC deposition into the deeper soil. As time goes on, organic mulch gradually decomposes and $\mathrm{MBC}$ and DOC increase. The increasing availability of nutrients in the soil increases the carbon content of the leaves through greater photosynthesis, and more elements are introduced to the rhizosphere by the fine roots. In the growing season, the leaf biomass increases with the growth of plants and the distribution of carbon content per unit in the leaves decreases. Element input through roots and labile SOC fractions are continuously enhanced. Finally, in the nongrowing season (12 months after $\mathrm{OM}$ ), rhizosphere deposition and SOC increase. Lastly, the organic mulch in OM5 lost more carbon than other treatments over time (Fig. 2) suggesting that using lower amounts of organic mulch can enhance relative decomposition and nutrient utilisation by soil. More dynamic and long-term studies into the effect of $\mathrm{OM}$ on the soil environment in forest ecosystems should be carried out to understand its mechanism of action, particularly because of its impact on environmental factors and their interactions.

\section{Conclusions}

Our study showed that DOC is more sensitive to OM than the other labile carbon fractions. The SOC moved to deeper soil after $\mathrm{OM}$ and the carbon content in the fine roots increased in the subsoil. OM affected organic carbon fractions in the bulk soil more than in the rhizosphere. Frequently applying small quantities of organic mulch may be beneficial to the accumulation of $\mathrm{SOC}$ in urban forest management. Time after OM (season) had the greatest effect on SOC fractions, followed by soil layer; hence, these are important factors that need to be considered in future research.

\section{Supplementary Information}

The online version contains supplementary material available at https://doi. org/10.1186/s40663-020-00278-5.

\begin{abstract}
Additional file 1: Figure S1. Ratio of labile organic carbon fractions to soil organic carbon and $\mathrm{C} / \mathrm{N}$ ratio over time after organic mulching ( $X$ axis). Values are means \pm the standard error $(n=5)$. SOC: soil organic carbon; DOC: dissolved organic carbon; EOC: easilyoxidised organic carbon; MBC: microbial biomass carbon. OMO: control (no mulch); OM5: $5 \mathrm{~cm}$ mulch; OM10: $10 \mathrm{~cm}$ mulch; OM20: $20 \mathrm{~cm}$ mulch. DOC/SOC and MBC/SOC increased after organic mulching (OM) whereas they decreased in the rhizosphere after 12 months of OM (non-growing season). EOC/SOC decreased at the beginning of growing season ( 6 months after $\mathrm{OM})$, then increased, but then decreased again in the nongrowing season, especially in the topsoil $(0-20 \mathrm{~cm})$. C/N ratio decreased in growing season ( 6 months and 9 months after OM) compared with OM0 and increased in non-growing season. Table S1. Pearson correlation coefficients among soil organic carbon fractions. Table S2. Pearson correlation coefficients among soil organic carbon fractions and environmental properties in soil and plant. Table S3. Analysis of variance of the effects of different treatments, soil layers, and time after organic mulching on rhizosphere effects for soil carbon fractions.
\end{abstract}

\section{Abbreviations}

BD: Bulk density; C/N: Carbon-nitrogen ratio; EOC: Easily-oxidised organic carbon; ICP-AES: Inductively coupled plasma-atomic emission spectroscopy; MBC: Microbial biomass carbon; OM: Organic mulching; OMO: Control (no mulch); OM5: 5-cm mulch; OM10: 10-cm mulch; OM20: 20-cm mulch; SOC: Soil organic carbon

\section{Acknowledgements}

We gratefully acknowledge the Administration of the Dr. Sun Yat-sen Mausoleum for providing the experimental area and the labor support at the site.

\section{Authors' contributions}

Q Guan and X Sun conceived and designed the experiments, DL Jones developed methodology. X Sun and G Wang performed the experiments. $X$ Sun and J Liao analysed the data. X Sun wrote the manuscript; other authors provided editorial advice. The authors read and approved the final manuscript.

\section{Funding}

This work was supported by the National Key Research and Development Program of China (No. 2016YFC0502703); Priority Academic Program Development of Jiangsu Higher Education Institutions (PAPD); and Postgraduate Research \& Practice Innovation Program of Jiangsu Province.

Availability of data and materials Not applicable.

Ethics approval and consent to participate Not applicable.

Consent for publication Not applicable.

Competing interests

The authors declare they have no competing interests. 


\section{Author details}

College of Biology and Environment, Nanjing Forestry University, Nanjing 210037, China. ${ }^{2}$ Co-Innovation Center of Sustainable Forestry in Southern China, Nanjing 210037, China. ${ }^{3}$ School of Natural Sciences, Bangor University, Gwynedd LL57 2UW, UK. ${ }^{4}$ College of Environmental Science and Engineering, China West Normal University, Nanchong 637000, China. ${ }^{5}$ UWA School of Agriculture and Environment, The University of Western Australia, Perth, WA 6009, Australia.

\section{Received: 28 March 2020 Accepted: 15 December 2020}

\section{Published online: 06 January 2021}

\section{References}

Angst G, Messinger J, Greiner M, Häusler W, Hertel D, Kirfel K, Kögel-Knabner I, Leuschner C, Rethemeyer J, Mueller CW (2018) Soil organic carbon stocks in topsoil and subsoil controlled by parent material, carbon input in the rhizosphere, and microbial-derived compounds. Soil Biol Biochem 122:19-30. https://doi.org/10.1016/j.soilbio.2018.03.026

Balland-Bolou-Bi C, Bolou-Bi EB, Alphonse V, Giusti-Miller S, Jusselme MD, Livet A, Grimaldi M, Bousserhine N (2019) Impact of microbial activity on the mobility of metallic elements (Fe, Al and hg) in tropical soils. Geoderma 334:146-154. https://doi.org/10.1016/j.geoderma.2018.07.044

Bates D, Mächler M, Bolker BM, Walker SC (2015) Fitting linear mixed-effects models using Ime4. J Stat Softw 67(1):1-48. https://doi.org/10.18637/jss.v067.i01

Birkhofer K, Bezemer TM, Bloem J, Bonkowski M, Christensen S, Dubois D, Ekelund F, Fließbach A, Gunst L, Hedlund K, Mäder P, Mikola J, Robin C, Setälä H, Tatin-Froux F, Van der Putten WH, Scheu S (2008) Long-term organic farming fosters below and aboveground biota: implications for soil quality, biological control and productivity. Soil Biol Biochem 40(9):22972308. https://doi.org/10.1016/j.soilbio.2008.05.007

Björk RG, Majdi H, Klemedtsson L, Lewis-Jonsson L, Molau U (2007) Long-term warming effects on root morphology, root mass distribution, and microbial activity in two dry tundra plant communities in northern Sweden. New Phytol 176(4):862-873. https://doi.org/10.1111/j.1469-8137.2007.02231.x

Blair GJ, Lefroy RD, Lisle L (1995) Soil carbon fractions based on their degree of oxidation, and the development of a carbon management index for agricultural systems. Aust J Agric Res 46(7):1459-1466. https://doi.org/10. 1071/AR9951459

Borchard N, Bulusu M, Meyer N, Rodionov A, Herawati H, Blagodatsky S, Cadisch G, Welp G, Amelung W, Martius C (2019) Deep soil carbon storage in treedominated land use systems in tropical lowlands of Kalimantan. Geoderma 354:UNSP113864. https://doi.org/10.1016/j.geoderma.2019.07.022

Brookes PC, Landman A, Pruden G, Jenkinson DS (1985) Chloroform fumigation and the release of soil nitrogen: a rapid direct extraction method to measure microbial biomass nitrogen in soil. Soil Biol Biochem 17(6):837-842. https:// doi.org/10.1016/0038-0717(85)90144-0

Chen X, Chen HYH (2018) Global effects of plant litter alterations on soil $\mathrm{CO}_{2}$ to the atmosphere. Glob Chang Biol 24(8):3462-3471. https://doi.org/10.1111/ gcb.14147

Chen Y, Cao J, Zhao J, Wu J, Zou X, Fu S, Zhang W (2019) Labile C dynamics reflect soil organic carbon sequestration capacity: understory plants drive topsoil C process in subtropical forests. Ecosphere 10(6):e02784. https://doi. org/10.1002/ecs2.2784

Cheng W, Parton WJ, Gonzalez-Meler MA, Phillips R, Asao S, Mcnickle GG, Brzostek E, Jastrow JD (2014) Synthesis and modeling perspectives of rhizosphere priming. New Phytol 201(1):31-44. https://doi.org/10.1111/nph. 12440

De Feudis M, Cardelli V, Massaccesi L, Hofmann D, Berns AE, Bol R, Cocco S, Corti G, Agnelli A (2017) Altitude affects the quality of the water-extractable organic matter (WEOM) from rhizosphere and bulk soil in European beech forests. Geoderma 302:6-13. https://doi.org/10.1016/j.geoderma.2017.04.015

Dong Q, Yang Y, Yu K, Feng H (2018) Effects of straw mulching and plastic film mulching on improving soil organic carbon and nitrogen fractions, crop yield and water use efficiency in the loess plateau, China. Agric Water Manag 201:133-143. https://doi.org/10.1016/j.agwat.2018.01.021

Fontaine S, Barot S, Barré P, Bdioui N, Mary B, Rumpel C (2007) Stability of organic carbon in deep soil layers controlled by fresh carbon supply. Nature 450(7167):277-280. https://doi.org/10.1038/nature06275

García-Díaz A, Marqués MJ, Sastre B, Bienes R (2018) Labile and stable soil organic carbon and physical improvements using groundcovers in vineyards from
Central Spain. Sci Total Environ 621:387-397. https://doi.org/10.1016/j. scitotenv.2017.11.240

Gu C, Liu Y, Mohamed I, Zhang R, Wang X, Nie X, Jiang M, Brooks M, Chen F, Li Z (2016) Dynamic changes of soil surface organic carbon under different mulching practices in citrus orchards on sloping land. PLoS One 11(12): e0168384. https://doi.org/10.1371/journal.pone.0168384

Haynes RJ, Mokolobate MS (2001) Amelioration of Al toxicity and P deficiency in acid soils by additions of organic residues: a critical review of the phenomenon and the mechanisms involved. Nutr Cycl Agroecosyst 59(1):4763. https://doi.org/10.1023/A:1009823600950

Hicks Pries CE, Sulman BN, West C, O'Neill C, Poppleton E, Porras RC, Castanha C, Zhu B, Wiedemeier DB, Torn MS (2018) Root litter decomposition slows with soil depth. Soil Biol Biochem 125:103-114. https://doi.org/10.1016/j.soilbio. 2018.07.002

Jandl R, Lindner M, Vesterdal L, Bauwens B, Baritz R, Hagedorn F, Johnson DW, Minkkinen K, Byrne KA (2007) How strongly can forest management influence soil carbon sequestration? Geoderma 137(3-4):253-268. https://doi. org/10.1016/j.geoderma.2006.09.003

Jing X, Chen X, Fang J, Ji C, Shen H, Zheng C, Zhu B (2020) Soil microbial carbon and nutrient constraints are driven more by climate and soil physicochemical properties than by nutrient addition in forest ecosystems. Soil Biol Biochem 141:107657. https://doi.org/10.1016/j.soilbio.2019.107657

Jones DL, Willett VB (2006) Experimental evaluation of methods to quantify dissolved organic nitrogen (DON) and dissolved organic carbon (DOC) in soil. Soil Biol Biochem 38(5):991-999. https://doi.org/10.1016/j.soilbio.2005.08.012

Kawahigashi M, Sumida H, Yamamoto K (2003) Seasonal changes in organic compounds in soil solutions obtained from volcanic ash soils under different land uses. Geoderma 113(3-4):381-396. https://doi.org/10.1016/S0016$7061(02) 00371-3$

Kuzyakov Y (2010) Priming effects: interactions between living and dead organic matter. Soil Biol Biochem 42(9):1363-1371. https://doi.org/10.1016/j.soilbio. 2010.04.003

Kuzyakov Y, Friedel JK, Stahr K (2000) Review of mechanisms and quantification of priming effects. Soil Biol Biochem 32(11-12):1485-1498. https://doi.org/10. 1016/S0038-0717(00)00084-5

Kuzyakov Y, Razavi BS (2019) Rhizosphere size and shape: temporal dynamics and spatial stationarity. Soil Biol Biochem 135:343-360. https://doi.org/10.1016/j. soilbio.2019.05.011

Kuzyakov Y, Xu X (2013) Competition between roots and microorganisms for nitrogen: mechanisms and ecological relevance. New Phytol 198(3):656-669. https://doi.org/10.1111/nph.12235

Lenka NK, Lal R (2013) Soil aggregation and greenhouse gas flux after 15 years of wheat straw and fertilizer management in a no-till system. Soil Tillage Res 126:78-89. https://doi.org/10.1016/j.still.2012.08.011

Li S, Li X, Zhu W, Chen J, Tian X, Shi J (2019) Does straw return strategy influence soil carbon sequestration and labile fractions? Agron J 111(2):897-906. https://doi.org/10.2134/agronj2018.08.0484

Li S, Zhang S, Pu Y, Li T, Xu X, Jia Y, Deng O, Gong G (2016) Dynamics of soil labile organic carbon fractions and C-cycle enzyme activities under straw mulch in Chengdu plain. Soil Tillage Res 155:289-297. https://doi.org/10. 1016/j.still.2015.07.019

Li Y, Jiang P, Chang SX, Wu J, Lin L (2010) Organic mulch and fertilization affect soil carbon pools and forms under intensively managed bamboo (Phyllostachys praecox) forests in Southeast China. J Soils Sediments 10(4): 739-747. https://doi.org/10.1007/s11368-010-0188-4

Li Y, Zhang J, Chang SX, Jiang P, Zhou G, Fu S, Yan E, Wu J, Lin L (2013) Longterm intensive management effects on soil organic carbon pools and chemical composition in Moso bamboo (Phyllostachys pubescens) forests in subtropical China. For Ecol Manag 303:121-130. https://doi.org/10.1016/j. foreco.2013.04.021

Nawaz A, Lal R, Shrestha RK, Faroog M (2017) Mulching affects soil properties and greenhouse gas emissions under long-term no-till and plough-till systems in Alfisol of Central Ohio. L Degrad Dev 28(2):673-681. https://doi.org/10.1002/ Idr.2553

Oksanen J, Blanchet FG, Friendly M, Kindt R, Legendre P, Mcglinn D, Minchin PR, O'hara R, Simpson GL, Solymos P, Henry M, Stevens H, Szoecs E, Maintainer HW (2019) Vegan: community ecology package. R package version 2, pp 5-5 https://CRAN.R-project.org/package=vegan. Accessed 20 Mar 2020

Phillips RP, Fahey TJ (2007) Fertilization effects on fineroot biomass, rhizosphere microbes and respiratory fluxes in hardwood forest soils. New Phytol 176(3): 655-664. https://doi.org/10.1111/j.1469-8137.2007.02204.x 
Phillips RP, Finzi AC, Bernhardt ES (2011) Enhanced root exudation induces microbial feedbacks to $\mathrm{N}$ cycling in a pine forest under long-term $\mathrm{CO}_{2}$ fumigation. Ecol Lett 14(2):187-194. https://doi.org/10.1111/j.1461-0248.2010. 01570.x

Pramanik P, Bandyopadhyay KK, Bhaduri D, Bhattacharyya R, Aggarwal P (2015) Effect of mulch on soil thermal regimes - a review. Int J Agric Environ Biotechnol 8(3):645-658. https://doi.org/10.5958/2230-732X.2015.00072.8

R Development Core Team (2018) R: a language and environment for statistical computing. Vienna, Austria https://www.R-project.org. Accessed 20 Mar 2020

Ramírez PB, Fuentes-Alburquenque S, Díez B, Vargas I, Bonilla CA (2020) Soil microbial community responses to labile organic carbon fractions in relation to soil type and land use along a climate gradient. Soil Biol Biochem 141: 107692. https://doi.org/10.1016/j.soilbio.2019.107692

Sainepo BM, Gachene CK, Karuma A (2018) Assessment of soil organic carbon fractions and carbon management index under different land use types in Olesharo catchment, Narok County, Kenya. Carbon Balance Manag 13:1. https://doi.org/10.1186/s13021-018-0091-7

Sasse J, Martinoia E, Northen T (2018) Feed your friends: do plant exudates shape the root microbiome? Trends Plant Sci 23(1):25-41. https://doi.org/10.1016/j. tplants.2017.09.003

Shao X, Yang W, Wu M (2015) Seasonal dynamics of soil labile organic carbon and enzyme activities in relation to vegetation types in Hangzhou Bay tidal flat wetland. PLoS One 10(11):e0142677. https://doi.org/10.1371/journal.pone. 0142677

Shen Y, Cheng R, Xiao W, Yang S, Guo Y, Wang N, Zeng L, Lei L, Wang X (2018) Labile organic carbon pools and enzyme activities of Pinus massoniana plantation soil as affected by understory vegetation removal and thinning. Sci Rep 8:573. https://doi.org/10.1038/s41598-017-18812-x

Sinsabaugh RL, Shah JJF, Findlay SG, Kuehn KA, Moorhead DL (2015) Scaling microbial biomass, metabolism and resource supply. Biogeochemistry 122(23):175-190. https://doi.org/10.1007/s10533-014-0058-z

Sokol NW, Kuebbing SE, Karlsen-Ayala E, Bradford MA (2019) Evidence for the primacy of living root inputs, not root or shoot litter, in forming soil organic carbon. New Phytol 221(1):233-246. https://doi.org/10.1111/nph.15361

State Forestry Administration of China (2014) Forest resources in China http:// www.china-ceecforestry.org/wp-content/uploads/2019/08/Forest-Resourcesin-China\%E2\%80\%94\%E2\%80\%94The-9th-National-Forest-Inventory.pdf. Accessed 20 Mar 2020

Sun X, Tang Z, Ryan MG, You Y, Sun OJ (2019) Changes in soil organic carbon contents and fractionations of forests along a climatic gradient in China. For Ecosyst 6:1. https://doi.org/10.1186/s40663-019-0161-7

Vogel JG, He D, Jokela EJ, Hockaday W, Schuur EAG (2015) The effect of fertilization levels and genetic deployment on the isotopic signature, constituents, and chemistry of soil organic carbon in managed loblolly pine (Pinus taeda L.) forests. For Ecol Manag 355:91-100. https://doi.org/10.1016/j. foreco.2015.05.020

Wang D, Chen X, Chen HYH, Olatunji OA, Guan Q (2019a) Contrasting effects of thinning on soil $\mathrm{CO}_{2}$ emission and above- and belowground carbon regime under a subtropical Chinese fir plantation. Sci Total Environ 690:361-369. https://doi.org/10.1016/j.scitotenv.2019.06.417

Wang J, Fu X, Sainju UM, Zhao F (2018) Soil carbon fractions in response to straw mulching in the loess plateau of China. Biol Fertil Soils 54(4):423-436. https:// doi.org/10.1007/s00374-018-1271-z

Wang J, Song C, Wang X, Song Y (2012) Changes in labile soil organic carbon fractions in wetland ecosystems along a latitudinal gradient in Northeast China. Catena 96:83-89. https://doi.org/10.1016/j.catena.2012.03.009

Wang Y, Zhang X, Chen J, Chen A, Wang L, Guo X, Niu Y, Liu S, Mi G, Gao Q (2019b) Reducing basal nitrogen rate to improve maize seedling growth, water and nitrogen use efficiencies under drought stress by optimizing root morphology and distribution. Agric Water Manag 212:328-337. https://doi. org/10.1016/j.agwat.2018.09.010

Wu J, Joergensen RG, Pommerening B, Chaussod R, Brookes PC (1990) Measurement of soil microbial biomass $C$ by fumigation-extraction-an automated procedure. Soil Biol Biochem 22(8):1167-1169. https://doi.org/10. 1016/0038-0717(90)90046-3

Xue JF, Pu C, Zhao X, Wei YH, Zhai YL, Zhang XQ, Lal R, Zhang HL (2018) Changes in soil organic carbon fractions in response to different tillage practices under a wheat-maize double cropping system. L Degrad Dev 29(6): 1555-1564. https://doi.org/10.1002/ldr.2950

York LM, Carminati A, Mooney SJ, Ritz K, Bennett MJ (2016) The holistic rhizosphere: integrating zones, processes, and semantics in the soil influenced by roots. J Exp Bot 67(12):3629-3643. https://doi.org/10.1093/jxb/ erw108

Zhang H, Tang J, Liang S, Li Z, Wang J, Wang S (2018) Early thawing after snow removal and no straw mulching accelerates organic carbon cycling in a paddy soil in Northeast China. J Environ Manag 209:336-345. https://doi.org/ 10.1016/j.jenvman.2017.12.069

Zhou Z, Zeng X, Chen K, Li Z, Guo S, Shangguan Y, Yu H, Tu S, Qin Y (2019) Long-term straw mulch effects on crop yields and soil organic carbon fractions at different depths under a no-till system on the Chengdu plain, China. J Soils Sediments 19(5):2143-2152. https://doi.org/10.1007/s11368-01802234-x

\section{Submit your manuscript to a SpringerOpen ${ }^{\circ}$ journal and benefit from:}

- Convenient online submission

- Rigorous peer review

- Open access: articles freely available online

- High visibility within the field

- Retaining the copyright to your article

Submit your next manuscript at $\boldsymbol{\nabla}$ springeropen.com 